\title{
細小肝癌症例に関する臨床的検討
}

\author{
森本哲雄, 波多野 裕, 永富裕二, 菩山浩子 \\ 田尻三昭, 村田欣也, 水田実
}

\section{I 。緒}

言

原発性肝細胞癌 (以下肝癌) は悪性腫瘍のなかでも, とくに予後不良の疾患である。しかし，この数年に拉 けるCT-scan, 腹部超音波検査, angiography など画 像診断法の進歩により, 肝癌の早期発見が可能となり, いわゆる細小肝癌の症例報告が増加してきた。しかし， 細小肝癌症例は肝硬変症の合併率が高いため, 肝機能 低下例が多く, 外科切除の適応とならない症例がある ことや, 細小肝癌の病理学的意義などまだ多くの問題 がある。

われわれは，当院に扮いて経験した細小肝癌症例に ついて臨床的に検討し, 若干の知見を得たので報告す る。な技, 細小肝癌とは, 1976年の日本肝癌研究会の 定義 ${ }^{1)}$ である「腫瘤 1 個最大径 $5 \mathrm{~cm}$ 以下，または主腫 瘤 $4 \mathrm{~cm}$ 以内で娘病巣数個以内のもの」とした。

\section{II．研究方法おょび成績}

昭和 54 年から昭和 58 年 7 月末までの間に，われわれ の施設に打いて経験した肝癌患者は69例である（表 1 )。平均年令 61.6 才, 男女比 $2.9: 1, \mathrm{HBs}$ 抗原陽性 例は 16 例 $23 \%$, 肝硬変 (LC) 合併例は 50 例 $72 \%$ であっ

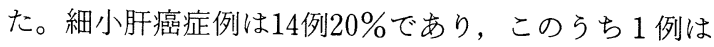

表 1. 肝癌患者の年度別発生状況

\begin{tabular}{c|ccccc}
\hline 年 度 & 症例数 & $\begin{array}{c}\text { 平均 } \\
\text { 年令 }\end{array}$ & $\begin{array}{c}\mathrm{HBsAg} \\
(+)\end{array}$ & $\begin{array}{c}\mathrm{LC} \\
\text { 合併例 }\end{array}$ & 細小肝癌 \\
\hline 昭和54年 & $8^{\text {例 }}$ & $61.1^{\text {扌 }}$ & $1^{\text {例 }}$ & 5 例 & 0 例 \\
55 & 17 & 62.3 & 4 & 16 & 4 \\
56 & 12 & 58.1 & 5 & 10 & 1 \\
57 & 17 & 62.6 & 5 & 12 & 5 \\
58 年7月末 & 15 & 63.8 & 1 & 7 & 4 \\
\hline 合 計 & 69 & 61.6 & 16 & 50 & 14 \\
& & & $(23 \%)$ & $(72 \%)$ & $(20 \%)$
\end{tabular}

表 2. 細小肝癌患者の内訳

\begin{tabular}{|c|c|c|c|c|c|c|}
\hline 症 & 例 & 疑診の動機 & $\mathrm{HBs} \mathrm{Ag}$ & L C & 発見の手段 & 腫瘍の大きさ $(\mathrm{cm})$ \\
\hline (1) M. O. & $71 \hat{\delta}$ & 黄 疽 & $(+)$ & $(+)$ & エコー & $2.0 \times 2.2$ \\
\hline (2) Ma. O. & 57 우 & $\mathrm{AFP}$ 上昇 & $(-)$ & $(+)$ & エコー & $2.0 \times 2.5$ \\
\hline (3) K. W. & $46 \hat{\jmath}$ & $\mathrm{AFP}$ 上昇 & $(-)$ & $(+)$ & $\mathrm{CT}$ & $3.4 \times 3.8$ \\
\hline (4) T. U. & 47 令 & 肝硬変の精査 & $(-)$ & $(+)$ & アンギオ & $1.5 \times 1.6$ \\
\hline (5) K. F. & $63 \hat{\jmath}$ & $\gamma$ - GPT 上昇 & $(-)$ & $(-)$ & $\mathrm{CT}$ & $2.8 \times 2.5$ \\
\hline (6) Y. E. & $64 \hat{\delta}$ & $\mathrm{AFP}$ 上昇 & $(-)$ & $(+)$ & エコー & $4.0 \times 3.0$ \\
\hline (7) M. I. & 48 우 & $\mathrm{AFP}$ 上昇 & $(-)$ & $(+)$ & $\mathrm{CT}$ & $3.0 \times 3.0$ \\
\hline (8) C. S. & 56 & 慢性肝炎の精査 & $(-)$ & $(-)$ & $\mathrm{CT}$ & $1.7 \times 2.0$ \\
\hline (9) T. K. & $61 \hat{\circ}$ & 肝硬変の精査 & $(-)$ & $(+)$ & エコー & $5.0 \times 3.0$ \\
\hline (10) Y. N. & $78 \hat{\jmath}$ & 肝硬変の精査 & $(-)$ & $(+)$ & $\mathrm{CT}$ & $3.2 \times 2.5$ \\
\hline (11) S. O. & $54 \hat{\jmath}$ & $\mathrm{AFP}$ 上昇 & $(-)$ & $(-)$ & $\mathrm{CT}$ & $3.0 \times 2.5$ \\
\hline (12) K. Y. & 54 소 & $\mathrm{AFP}$ 上昇 & $(-)$ & $(+)$ & アンギオ & $2.5 \times 2.0$ \\
\hline (13) M. F. & 58 & 肝硬変の精查 & $(-)$ & $(+)$ & エコー & $2.2 \times 2.2$ \\
\hline
\end{tabular}

* 山口県厚生連周東総合病院内科 受付：昭和 58 年 10 月 24 日 
多発性骨髄腫で死亡し，剖検によって偶然細小肝癌が 発見された症例である。この剖検によって発見された 1 例を除く13例について, 以下の臨床的検討を行なっ た。

細小肝癌症例13例の内訳を表 2 に示した。平均年令 は58.2才, 男女比は5.5：1であった。疑診の動機とし ては $\alpha$-fetoprotein (以下 AFP) の上昇がもっとも多 <6 例, ついで肝硬変の精査が 4 例, あと黄疸, $\gamma$-GTP の上昇, 慢性肝炎の精査が各 1 例であった。発見の手 段としては CT-Scan が 6 例, 腹部超音波検查(以下腹 部エコー) 5 例, angiography（アンギオ） 2 例であっ た。HBs 抗原陽性例は 1 例のみであった。肝硬変の合 併は10例77\%にみとめられた。また娘病巣を伴なった 症例は 3 例であり, 表 2 の症例(6)(9)(12)であった。症例 (6)は右葉に主腫瘤があり, 左葉に $2.0 \times 2.0 \mathrm{~cm}$ の娘病 巣をみとめた。症例(9)(12)はともに主腫瘤は右葉にあり, 娘病巣も右葉に存在した。大きさは症例 $(9)$ は $1.0 \times 1.0$ $\mathrm{cm}$, 症例(12)は娘病巣が 2 個あり, $1.5 \times 1.5 \mathrm{~cm}$ およよ゙ $1.0 \times 1.0 \mathrm{~cm}$ であった。

つぎに, 細小肝癌症例の腫瘍マーカーについて検討 した(表 $\left.3^{\prime}\right)$ 。表のごとく, AFP が $400 \mathrm{ng} / \mathrm{m} \ell$ 以上を 示したのは 5 例 $38 \%$ であった。 AFP が $400 \mathrm{ng} / \mathrm{m} \ell$ 末 満であった残り 8 例のうち, $\beta_{2}$-microglobulin が上昇 した症例 2 例, ferritin が上昇した症例 1 例であった。 したがって, 細小肝癌13例のうち 5 例38\%は腫瘍マー カーで check できなかった。

表 4 に細小肝癌症例の画像診断法について示した。

表 3 ．細小肝癌症例の腫瘍マーカー

\begin{tabular}{l|rccc}
\hline 症 例 & AFP & $\beta_{2}-\mathrm{M}$ & CEA & Ferritin \\
\hline (1) M. O. & 44 & ND & ND & ND \\
(2) Ma. O. & 581 & 1.8 & ND & ND \\
(3) K. W. & 738 & 1.6 & 1.9 & ND \\
(4) T. U. & 121 & 3.4 & 3.1 & ND \\
(5) K. F. & $(-)$ & 1.6 & 1.7 & 67 \\
(6) Y. E. & 1600 & 6.5 & 12 & 285 \\
(7) M. I. & 25600 & 2.0 & 3.8 & 13 \\
(8) C. S. & $(-)$ & 3.4 & 3.9 & 180 \\
(9) T. K. & $(-)$ & 2.4 & 4.3 & ND \\
(10) Y. N. & $(-)$ & 2.0 & 3.7 & 210 \\
(11) S. O. & 445 & ND & 6.7 & 160 \\
(12) K. Y. & 115 & 1.9 & 5.0 & 660 \\
(13) M. F. & $(-)$ & 1.1 & 2.3 & 102 \\
& \multicolumn{5}{|c}{ ND : not examined } \\
& $\beta_{2}$ - M. : $\beta_{2}$-microglobulin
\end{tabular}

スクリーニングとして腹部エコーとCT-scan が施行 され, 確定診断として angiography が施行された。し かし, 細小肝癌症例の場合, 腫瘍そのものが小さいた めに, tumor stain として認めることが困難な症例も あり，そのような症例ではェコーガイド下吸引細胞診 によって最終的に診断した。

細小肝癌症例の治療と予後について表 5 に示した。 手術施行例は 7 例であり, そのうち 1 例は transcath-

表 4 ．細小肝癌症例の画像診断

\begin{tabular}{|c|c|c|c|c|c|}
\hline 症 例 & $\begin{array}{l}\text { 腹部 } \\
\text { エコー }\end{array}$ & $\mathrm{CT}$ & アンギオ & 腹腔鏡 & $\begin{array}{c}\text { 確定診断 } \\
\text { の方法 }\end{array}$ \\
\hline (1) M. O. & 0 & 0 & 0 & 0 & アンギオ \\
\hline (2) Ma. O. & 0 & 0 & 0 & $\bullet$ & アンギオ \\
\hline (3) K. W. & 0 & 0 & 0 & 0 & アンギオ \\
\hline (4) T. U. & 0 & 0 & 0 & 0 & アンギオ \\
\hline (5) K. F. & 0 & 0 & 0 & 0 & アンギオ \\
\hline (6) Y. E. & 0 & 0 & 0 & $\bullet$ & アンギオ \\
\hline (7) M. I. & 0 & 0 & 0 & $\times$ & アンギオ \\
\hline (8) C. S. & 0 & 0 & - & $\bullet$ & 吸引細胞診 \\
\hline (9) T. K. & 0 & 0 & 0 & 0 & アンギオ \\
\hline (10) Y. N. & 0 & 0 & 0 & $\times$ & アンギオ \\
\hline (11) S. O. & $\bullet$ & 0 & 0 & $\times$ & アンギオ \\
\hline (12) K. Y. & $\bullet$ & 0 & 0 & $x$ & アンギオ \\
\hline (13) M. F. & 0 & $\bullet$ & $\bullet$ & $\bullet$ & 吸引細胞診 \\
\hline \multicolumn{3}{|c|}{ 表 5. 細小肝癌症例の治療と予後 } & \multicolumn{3}{|c|}{$\times$ not examined } \\
\hline 症 例 & \multicolumn{3}{|c|}{ 主な治療内容 } & 予 & 後 \\
\hline (1) M. O. & \multicolumn{3}{|c|}{ 肝部分切除術 } & \multicolumn{2}{|c|}{$\begin{array}{l}\text { 術後11か月で死亡 } \\
\text { (他部位再発) }\end{array}$} \\
\hline (2) Ma. O. & \multicolumn{3}{|c|}{ 右葉切除術 } & \multicolumn{2}{|c|}{$\begin{array}{r}\text { 術後 } 8 \text { 日目に死亡 } \\
\text { (肝不全) }\end{array}$} \\
\hline (3) K. W. & \multicolumn{3}{|c|}{ TAE 後, 肝部分切除術 } & \multicolumn{2}{|c|}{ 術後 1 年11か月生存中 } \\
\hline (4) T. U. & \multicolumn{3}{|c|}{ 肝部分切除術 } & \multicolumn{2}{|c|}{ 術後 2 年 8 少月生存中 } \\
\hline (5) K. F. & \multicolumn{3}{|c|}{ 肝部分切除術 } & \multicolumn{2}{|c|}{ 術後 1 年 2 召月生存中 } \\
\hline (6) Y. E. & \multicolumn{3}{|c|}{ TAE, ADM one shot } & \multicolumn{2}{|c|}{ 診断後 1 年 2 加月生存中 } \\
\hline (7) M. I. & \multicolumn{3}{|c|}{ フトラフール内服 } & \multicolumn{2}{|c|}{ 診断後 1 年 6 か月で死亡 } \\
\hline (8) C. S. & \multicolumn{3}{|c|}{ 肝部分切除術 } & \multicolumn{2}{|c|}{ 術後11か月生存中 } \\
\hline (9) T. K. & \multicolumn{3}{|c|}{$\mathrm{ADM}, \mathrm{MMC}$ one shot } & \multicolumn{2}{|c|}{ 診断後 1 年 6 か月で死亡 } \\
\hline (10) Y. N. & \multicolumn{3}{|c|}{ ADM, MMC one shot } & \multicolumn{2}{|c|}{ 診断後 6 加月生存中 } \\
\hline (11) S. O. & \multicolumn{3}{|c|}{ 肝部分切除術 } & \multicolumn{2}{|c|}{$\begin{array}{l}\text { 術後 } 5 \text { か月生存中 } \\
\text { (ただし他部位再発) }\end{array}$} \\
\hline (12) K. Y. & \multicolumn{3}{|c|}{$\mathrm{ADM}, \mathrm{MMC}$ one shot } & \multicolumn{2}{|c|}{ 診断後 5 か月生存中 } \\
\hline (13) M. F. & \multicolumn{3}{|c|}{ フトラフール内服 } & \multicolumn{2}{|c|}{$\begin{array}{r}\text { 診断後 } 2 \text { か月で死亡 } \\
\text { (イレウス) }\end{array}$} \\
\hline
\end{tabular}


$980(78)$

表 6. 細小肝癌患者の肝機能 (平均値)

\begin{tabular}{|c|c|c|c|c|c|c|c|}
\hline & $\begin{array}{l}\text { Alb. } \\
(\mathrm{g} / \mathrm{dl})\end{array}$ & $\begin{array}{l}\mathrm{ChE} \\
(\Delta \mathrm{pH})\end{array}$ & $\begin{array}{l}\mathrm{PT} \\
(\%)\end{array}$ & $\begin{array}{r}\mathrm{HPT} \\
(\%)\end{array}$ & $\begin{array}{c}{\text { ICG } \mathrm{R}_{15}}_{(\%)}\end{array}$ & $\begin{array}{l}\text { ICG Rmax } \\
(\mathrm{mg} / \mathrm{kg} / \mathrm{min})\end{array}$ & $\frac{\text { GOT }}{\text { GPT }}$ \\
\hline 手術施行例（6 例) & 3.6 & 0.61 & 86.5 & 76.7 & 11.6 & 1.83 & 1.66 \\
\hline $\begin{array}{l}\text { 手術非施行例 (6 例) } \\
\text { 及び術後死亡例 }(1 \text { 例 })\end{array}$ & 2.5 & 0.29 & 72.1 & 58.4 & 39.7 & ND & 2.0 \\
\hline
\end{tabular}

ND : not examined PT : prothrombin time HPT : hepaplastin test

表 7. 細小肝癌症例の病理組織学的所見

\begin{tabular}{|c|c|c|c|c|c|c|c|}
\hline \multirow[b]{2}{*}{ No. } & \multirow[b]{2}{*}{ 症 例 } & \multirow[b]{2}{*}{ 組織型 } & \multirow[b]{2}{*}{$\begin{array}{l}\text { Edmondson } \\
\text { 分 類 }\end{array}$} & 被膜形成 & \multirow[b]{2}{*}{$\begin{array}{c}\text { 被膜外浸潤 } \\
\text { (程度 mm) }\end{array}$} & \multirow[b]{2}{*}{$\begin{array}{l}\text { 脈 管 侵 襲 } \\
\text { (顕微鏡的) }\end{array}$} & \multirow[b]{2}{*}{ 非 癌 部 } \\
\hline & & & & $\begin{array}{l}\text { 肉眼的 顕微鏡的 } \\
\text { 完全 不完全 }\end{array}$ & & & \\
\hline 1 & (1) M. O. & 索状 & II & $(+) \quad(+)$ & $\begin{array}{c}(+) \\
(1 \mathrm{~mm})\end{array}$ & $(-)$ & 乙型肝硬変 \\
\hline 2 & (3) K. W. & 索状 & II & $(+)$ & $(+)^{*}$ & $(-)$ & 乙型肝硬変 \\
\hline 3 & (5) K. F. & 索状 & II & $(+)$ & $\begin{array}{c}(+) \\
(1 \mathrm{~mm})\end{array}$ & $(+)$ & 正常肝 \\
\hline 4 & (8) C. S. & $\begin{array}{l}\text { 索状 } \\
\text { 偽腺 }\end{array}$ & II & $(+) \quad(-) \quad(+)$ & $\begin{array}{l}(+) \\
(2 \mathrm{~mm})\end{array}$ & $(-)$ & 乙型肝硬変 \\
\hline 5 & (11) S. O. & 索状 & II & $(-)^{* *}(-) \quad(-)$ & $(-)^{* * *}$ & $(-)$ & 乙型肝硬変 \\
\hline
\end{tabular}

*：厚い被膜で被包されているが, 肝表面方向の 1 か所のみ肉眼的な娘結節を形成し, 母結節と癒合している。

**：腫瘍結節は小さな腫瘍細胞集団の集合より成り，各集団間には結合織の増生がある が，腫瘍結節全体を囲む被膜はない。

***：各腫瘍細胞集団は限局し, 周囲結合織への浸潤はない。

eter arterial embolization (TAE)後, 肝部分切除を施 行した。予後は術後 8 日目に肝不全で死亡した症例が 1 例, 11 力月目に他部位再発で死亡した症例が 1 例で あり，あとの 5 例は現在生存中である。しかし，この 中には，すでに他部位再発が確認された症例が 1 例含 まれている。手術できなかった 6 例の中には，比較的 長期間生存している症例もみられたが, 診断後 2 力月 や6カ月で死亡した症例もあった。

肝癌は切除のみが根治を期待できる治療法である が, 肝硬変を合併することが多いため, 手術に際して は肝機能予備力の程度が常に問題となる。表 6 に細小 肝癌手術施行例 6 例之手術非施行例 6 例（術後の肝不 全死 1 例を含む) の肝機能検査値を比較した。

細小肝癌切除例 7 例のうち, 病理組織学的に詳細な 検討が可能であった 5 例について，その所見を表 7 に 示した。それによれば組織型は 4 例が索状型であり,

Edmondson 分類では全例 grade II であった。被膜形 成は 4 例にみとめられたが， 4 例とも被膜外浸潤を 伴っていた。脈管侵襲（顕微鏡的）は 1 例にみられた。 また非癌部の組織は乙型肝硬変が 4 例, 正常肝が 1 例 であった。

\section{III. 考察}

肝癌治療において, 切除可能な肝癌を発見すること は重要なことであるが, 切除可能な小さい肝癌は臨床 所見に乏しく，これを早期に発見することはきわめて 困難である2)。一般に, 肝癌の high risk group である 慢性肝疾患とくに肝硬変症患者に対して, AFPをはじ めとする種々の腫瘍マーカーを頻回に測定し, 一方で は腹部ェコーやCT-scanなどの画像診断法を定期的 に施行して, 肝癌が疑われれば, angiographyを施行 し肝癌の診断がなされている。われわれの施設でも, 肝癌のスクリーニング法として，このような方法を用 い, 昭和54年以降13例の細小肝癌症例を経験した。細 小肝癌の定義は, 1976年の日本肝癌研究会の追跡調査 $(\text { 第 } 3 \text { 報 })^{1)}$ で最初になされているが，もっとも新しい 定義は, 1983年日本肝癌研究会の原発性肝癌取扱い規 約 ${ }^{3)}$ とると「最大径 $2 \mathrm{~cm}$ 末満の単発した肝癌」を small liver cancer と呼称している。今回われわれは 1976年の定義にしたがって, 最大径 $5 \mathrm{~cm}$ 以下の腫瘍 例について検討した。

疑診の動機としては, AFP の上昇によるものがもっ 
とも多く, A F P 測定の重要性が示唆された。しかし $\mathrm{AFP}$ 低産生性の細小肝癌も歹り, C E A, $\beta_{2}$-microglobulin, ferritin といった他の腫瘍マーカー を組合せて診断することが必要と思われた。

画像診断法としては、腹部エコーは患者に対する侵 襲がなく, 簡便な検査法であり, 細小肝癌のスクリー ニング法としてはもっともすぐれていると思われ る4)。さらに，われわれは angiography で確診できな かった 2 例の細小肝癌症例を, エコーガイド下吸引細 胞診で確診できた。CT-scanもきわめて有効な手段で あるが，経済性や被曝といった点で問題がある。

前述したように, 細小肝癌は肝硬変を合併すること が多いため, 手術に際しては肝機能予備力の程度が常 に問題となる55。またわれわれは, 細小肝癌でありなが ら,すでに脈管侵襲 (顕微鏡的) を打こした症例を経 験している。このような腫瘍の発育形式6) といった点 からも, これら細小肝癌症例においても, 長期生存の 可能性は必ずしも高くはないと思われる7)。細小肝癌 の診断と治療, また病理学的意義について, 今後さら に多くの研究が必要であろう。

\section{IV. 結語}

1)われわれの施設において経験した, 最大径 $5 \mathrm{~cm}$
以下の細小肝癌症例13例について, 臨床的に検討 した。

2）疑診の動機としては，AF Pの上昇がもっとも多 かった。

3 ) 画像診断のスクリーニング法としては, 腹部エ コーがもっとも有用と思われた。

4 ) 細小肝癌症例の予後は, 合併する肝硬変症の状態 に大きく左右されることが示唆された。

本論文の要旨は第32回日本農村医学会総会 (広島) に㧧いて発表した。

$$
\text { 文献 }
$$

1) 石川浩一：原発性肝癌に関する追跡調査一第 3 報一, 肝臓 $17: 460 \sim 465,1976$.

2) 奥田邦雄 : 微小肝癌, medicina, 15:1292-1293, 1978 .

3 ) 日本肝癌研究会編：臨㦿・病理原発性肝癌取扱い規約, 金原 出版, 東京, 1983, P 12 .

4 ）幕内雅敏他：内格 MOOK No. 18 肝癌, 金原出版, 東京, 1982, P 106 .

5 ) 水本龍二他：肝機能予備力と手術危険度の判定, 外科治療 $39: 71 \sim 78,1978$.

6 ) 武本憲重 : 原発性肝癌の病理形態学的研究, 肝細胞癌におけ る肝内発育先端部の超微細構造について, 肝臓 23 : 404 412, 1982.

7 ) 下山孝俊他：細小肝細胞癌の臨床一外科的切除症例の病態 と病理形態学的検討一, 肝臟 $21: 1008 \sim 1015,1980$.

\title{
Study on Clinical Findings of Patients with Minute Hepatocellular Carcinoma
}

\author{
Tetsuo Morimoto, Yutaka Hatano, Yuji Nagatomi, \\ Hiroko Sakiyama, Mitsuaki Tajiri, Kinya Murata \\ and Minoru Mizuta*
}

Thirteen patients with primary hepatocellular carcinoma less than $5 \mathrm{~cm}$ in size were seen in our clinic during the past four years. Clinical data of these patients were evaluated to clarify the clinical significance of minute hepatocellular carcinoma. Eleven of these patients were male, and average age was 58 years old. Of these patients, ten $(77 \%)$ were complicated by liver cirrhosis, and only one revealed positive HBs antigen in serum. The serum alpha-fetoprotein level showed more than $400 \mathrm{ng} /$ $\mathrm{ml}$ in five patients (38\%). And we thinked that ultrasonographic examinations were most effective to diagnose minute hepatocellular carcinoma in various diagnostic imaging methods.

Most of patients exhibited a decreased functional reserve in the liver, but seven patients underwent hepatic resection. After operation, one patient died of acute hepatic insufficiency on the 8 th day, and one died of the recurrence of tumor on the 11th month. Other five patients have been alive now.

It is suggested that the survival time of patients with minute hepatocellular carcinoma is fairly influenced by the condition of accompanied liver cirrhosis

* Shuto General Hospital, Yanai, Japan 